OPTIMUM. STUDIA EKONOMICZNE NR 3 (69) 2014

\author{
Jerzy ŚLESZYŃSKI ${ }^{1}$
}

\title{
PODATKI ŚRODOWISKOWE I PODZIAŁ NA GRUPY PODATKÓW WEDLUG METODYKI EUROSTATU
}

\begin{abstract}
Streszczenie
Artykuł został napisany na podstawie analizy nowej metodyki Eurostatu, będącej podstawą wspólnego projektu GUS-Eurostat pt:: European Environmental Economic Accounts: Module for Environmental Taxes (EEEA Tax). Celem opracowania jest krytyczne ustosunkowanie się do wybranych składników metodyki Eurostatu. Przedmiotem zainteresowania są należności, które, według kryteriów ustalonych przez Eurostat, można zakwalifikować jako podatki. Pierwszym i kluczowym rozstrzygnięciem jest wyodrębnienie podatków związanych ze środowiskiem. Podatkiem środowiskowym (environmental tax) jest podatek zidentyfikowany jako podatek w ramach metodyki ESA 95, którego podstawę stanowi jednostka fizyczna oddziaływania (lub substytut/zastępnik tej jednostki) o udowodnionym, negatywnym wpływie na środowisko. Kolejnym krokiem w ramach metodyki Eurostatu jest dokonanie podziału wyodrębnionych podatków środowiskowych na cztery, z góry ustalone, grupy: podatki energetyczne (energy taxes), podatki transportowe (transport taxes), podatki od zasobów naturalnych (resources taxes), podatki od zanieczyszczeń (pollution taxes). Podział ten nie jest oczywisty z racji szczególnego potraktowania podatków energetycznych, a także z powodu licznych, proponowanych wyłączeń podatków, które można byłoby zaliczyć do jednej z pozostałych grup podatków środowiskowych.
\end{abstract}

Słowa kluczowe: rachunki narodowe, podatki środowiskowe

\section{ECOLOGICAL TAXES AND THEIR CLASSIFICATION IN ACCORDANCE WITH EUROSTAT METHODOLOGY}

\section{Summary}

The paper is based on the author's analysis of the new Eurostat methodology which served as a guideline for a joint project of Eurostat and the Central Statistical Office, entitled: "European Environmental Economic Accounts: Module for Environmental Taxes (EEEA Tax)". Critical discussion of selected elements of the Eurostat methodology is the main objective of this paper. The analysis is focused on payments which fulfill Eurostat requirements. The first and crucial step was to identify environmental taxes. Environmental tax is one identified as a tax in the ESA 95 and whose tax base is a physical unit (or a proxy of a physical unit) of something that has been proven to have a specific negative impact on the environment. The next step in the Eurostat methodology is to divide all environmental taxes into four groups: energy taxes, transport taxes, resources taxes, and pollution taxes. This classification is not clear-cut, however, because of the specific importance given to energy taxes and the exclusion of several taxes which could be attributed to the remaining groups of taxes.

Key words: national accounts, environmental taxes

1 dr hab. Jerzy Śleszyński, prof. UW - Wydział Nauk Ekonomicznych Uniwersytetu Warszawskiego, Warszawski Ośrodek Ekonomii Ekologicznej; e-mail: sleszynski@wne.uw.edu.pl. 


\section{Ocena metodyki Eurostatu w zakresie podatków środowiskowych i ich podziału na grupy podatków}

\section{Wstęp}

Przedmiotem zainteresowania tego opracowania są zobowiązania podatkowe, które, według kryteriów ustalonych przez Eurostat, można zakwalifikować jako podatki środowiskowe. Sa to kwoty istotne w skali Unii Europejskiej oraz w skali każdego kraju. Eurostat postanowił zinwentaryzować je na podstawie jednorodnej i specjalnie przygotowanej metodyki. Do tego zadania powołano urzędy statystyczne krajów członkowskich - w Polsce jest to Główny Urząd Statystyczny. Specjalnie utworzona Grupa Zadaniowa do spraw Rachunków Środowiskowych Głównego Urzędu Statystycznego wspomagała prace nad projektem pilotowym, podjęte w Departamencie Studiów Regionalnych i Ochrony Środowiska wespół z innymi departamentami Głównego Urzędu Statystycznego.

Opracowanie nawiazzuje do wspólnego projektu GUS-Eurostat pt.: European Environmental Economic Accounts: Module for Environmental Taxes (EEEA Tax). Wymagania formalne, a więc definicje i klasyfikacje składające się na metodykę, zostały ustalone przez EUROSTAT. Merytorycznym źródłem informacji i odwołaniem dla badań krajowych, realizowanych w ramach projektu, były wybrane dokumenty Eurostatu [Environmental taxes..., 2001] i specjalne materiały szkoleniowe [Baud, Milota, 2010], które precyzują i aktualizują wcześniejsze ustalenia metodyki.

Zadanie badawcze postawione przed Grupa Zadaniowa GUS, z udziałem autora artykułu, zatytułowano: Opracowanie metodologii rachunku podatków zwiazanych ze środowiskiem w zakresie alokacji wielkości zagregowanych $w$ podżale na grupy podatków $i$ rodzajón driałalności wedtug NACE Rev.2 i składało się z dwóch etapów:

- Etap I: dokonanie podziału krajowych podatków na grupy podatków środowiskowych;

- Etap II: określenie kwot krajowych podatków środowiskowych w podziale na płatników według rodzaju działalności.

Opracowanie odnosi się tylko do pierwszego etapu i wykorzystuje materiał sporządzony przeze autora dla Głównego Urzędu Statystycznego i stanowiący podstawę określenia, po różnorakich konsultacjach i zmianach, krajowej listy podatków środowiskowych [Śleszyński, 2013]. Zostało napisane dzięki analizie nowej metodyki Eurostatu, będącej podstawą projektu. Opracowanie nie przedstawia ostatecznych wyników projektu. Celem artykułu jest krytyczne ustosunkowanie się do wybranych składników metodyki Eurostatu uwzględnionej w projekcie pilotowym dla Polski. Wnikliwa analiza stanowi głos w dyskusji nad słusznością i praktyczną przydatnością rozwiązań zaproponowanych przez Eurostat. W tekście zasygnalizowano również trudności, na jakie napotykała realizacja zadania badawczego. 


\section{Podatki środowiskowe}

Literatura dotycząca teoretycznych i praktycznych problemów opodatkowania jest niebywale rozległa, ale nie stanowi dla tego artykułu niezbędnego punktu odniesienia. Jego przesłanki są następujące: podatki są we współczesnym państwie niezbędnym sposobem zapewniania powszechnie akceptowanych i pożądanych dóbr publicznych, dobra i usługi środowiskowe, o określonej jakości, są w przeważającej części dostępne lub udostępniane dzięki wydatkom publicznym, podatki środowiskowe są istotnym zasileniem, wcześniej wymienionych, wydatków.

Potrzeba, czy wręcz konieczność, nakładania podatków związanych ze środowiskiem łączy się zarazem z oczekiwaniem, że niektóre z nich, poza funkcją fiskalną zapewniająca dochody podatkowe, moga także pełnić funkcję bodźcowa, zachęcając do obniżenia tej części kosztu działalności, która wynika z płacenia za negatywne oddziaływanie na środowisko. W krajach OECD, jak również w krajach Unii Europejskiej, prowadzona jest aktywna polityka ochrony środowiska, która posługuje się w coraz większym zakresie instrumentami ekonomicznymi, realizującymi funkcję fiskalna, w tym narzędziami podatkowymi.

W ostatnich dekadach, poprzedzających XXI wiek, zainteresowanie Unii Europejskiej podatkami obejmującymi środowisko spowodowało lawinę nowych opracowań dotyczących podatków uznanych za wiążące się ze środowiskiem oraz badań promujących ekologiczną reformę podatkową ${ }^{2}$. Pierwszy nurt to przede wszystkim wzmożenie prac nad uporządkowaniem metodyki podatków środowiskowych i określeniem, porównywalnej w skali międzynarodowej, wysokości wpływów z podatków środowiskowych w zestawieniu z całkowitymi wpływami podatkowymi oraz z PKB. W tym nurcie mieści się, omawiana w artykule, metodyka Eurostatu i analiza jej praktycznego zastosowania w polskich warunkach.

Pierwszym krokiem, zgodnym z metodyką Eurostatu, jest zawężenie pola obserwacji do zobowiązań spełniających warunki określone dla podatków. Przedmiotem zainteresowania są wyłącznie należności, które, według ustalonych kryteriów, można zakwalifikować jako podatki. Podatkiem jest obowiązkowa i nie dająca się uniknąc zapłata w gotówce lub w innej formie, nałożona przez rząd danego kraju lub instytucje Unii Europejskiej. Szczegóły określa metodyka ESA'95 w odniesieniu do podstawowych grup podatków: podatków od produkcji i przywozu (D.2), podatków dochodowych, majątkowych itd. (D.5), podatków od kapitału (D.91).

Nie ma ścisłej definicji podstawy opodatkowania dla podatków. W ramach ESA'95 została opracowana lista, która służy wyliczeniu przedmiotów opodatkowania dla podatków środowiskowych. Wykorzystano ją w trakcie dokonywania przeglądu krajowych podatków. Metodyka określa, jakiego rodzaju baza podatkowa może wchodzić w rachubę w przypadku podatków środowiskowych: zmierzone lub szacowane emisje do powietrza, substancje zubażające warstwę ozonowa, zmierzone lub oszacowane ścieki zrzucane do wód, niepunktowe źródła zanieczyszczeń wód, gospo-

${ }^{2} \mathrm{~W}$ polskiej literaturze jedna z pierwszych, przeglądowych prac na temat ekologicznej reformy podatkowej była publikacja J. Śleszyńskiego. Zob.: [Śleszyński, 2004]. 
darka odpadami, hałas, produkcja energii, produkty energetyczne, transport, zasoby naturalne.

Określono reguły kwalifikujące należność jako podatek, które nawiąują do podręczników ekonomii, jednak wprowadzając również pewne uściślenia. Podatek nie ma zapewniać usługi wyświadczanej płacącemu przez państwo lub jego instytucje. Podatek nie powinien być określony w sposób proporcjonalny, a więc przez stawkę powiązaną z ilością dostarczonej usługi. Jeżeli przynajmniej jeden z tych dwóch warunków (sformułowanych z użyciem zaprzeczenia!) jest spełniony, to dane zobowiązanie jest podatkiem. W metodyce i dalszych rozważaniach przyjmuje się zasadę memoriałowa, stąd mówi się o podatku należnym, wynikającym ze zobowiązania podatkowego.

Drugim krokiem metodyki jest wyodrębnienie podatków środowiskowych (environmental tax). Podatkiem środowiskowym jest podatek, zidentyfikowany jako podatek w ramach metodyki ESA'95, którego podstawa jest jednostka fizyczna oddziaływania o udowodnionym, negatywnym wpływie na środowisko. W przyjętym podejściu przedmiotem zainteresowania metodyki jest wyłącznie negatywne oddziaływanie na środowisko, skutkujące: zubożeniem zasobów naturalnych, zanieczyszczaniem środowiska i innymi formami pogorszenia jakości środowiska w skali lokalnej i globalnej. Wymienione reguły przejrzyście przedstawia tabela 1 .

TABELA 1.

\section{Kryteria kwalifikujące zobowiązanie jako podatek środowiskowy}

\begin{tabular}{|l|l|}
\hline \multicolumn{1}{|c|}{ Kryterium dla podatków } & \multicolumn{1}{c|}{ Kryterium dla podatku środowiskowego } \\
\hline Spełniony musi być przynajmniej jeden $\mathrm{z}$ wa- & Podatek środowiskowy musi mieć udokumen- \\
runków określonych dla podatków: & towany, szkodliwy wpływ na środowisko natu- \\
$\begin{array}{l}\text { 1. z podatkiem nie łączy się świadczenie usługi } \\
\text { lub }\end{array}$ & $\begin{array}{l}\text { ralne w przeliczeniu na fizyczna jednostkę ne- } \\
\text { gatywnego oddziaływania lub jego konkretnie }\end{array}$ \\
$\begin{array}{l}\text { 2. należny podatek nie jest proporcjonalny do } \\
\text { świadczonej usługi. }\end{array}$ & określonego zamiennika. \\
\hline
\end{tabular}

Źródło: opracowanie własne na podstawie materiałów Eurostatu.

Zgodność z bazą podatkową wymienioną w ESA'95 nie wystarcza, ponieważ trzeba jeszcze upewnić się, że ma się do czynienia z podatkiem środowiskowym według podanej wyżej definicji. Co bardzo ważne, występujące w kraju zobowiązania nałożone przez państwo i jego instytucje mogą zostać uznane za podatki, nawet jeśli nie noszą takiej nazwy lub nie są w ten sposób rejestrowane w rachunkach narodowych.

Kolejnym krokiem w ramach metodyki Eurostatu jest dokonanie podziału wyodrębnionych podatków środowiskowych na cztery, z góry ustalone, grupy: podatki od energii (energy taxes), podatki od transportu (transport taxes), podatki od zasobów naturalnych (resources taxes), podatki od zanieczyszczeń (pollution taxes). Podział ten jest, ogólnie rzecz ujmując, zrozumiały, jeżeli brać pod uwagę najistotniejsze formy działalności gospodarczej silnie i negatywnie wpływające na środowisko naturalne, co pokazuje tabela 2 . 
TABELA 2.

Kategorie podatków środowiskowych według Eurostatu

\begin{tabular}{|c|c|c|c|}
\hline \multicolumn{4}{|c|}{ Podatki środowiskowe } \\
\hline $\begin{array}{l}\text { Podatki od energii: } \\
\text { - } \quad \text { przede wszystkim } \\
\text { podatki od nośni- } \\
\text { ków energii: oleje } \\
\text { opałowe, gaz } \\
\text { ziemny, węgiel, } \\
\text { energia elektryczna } \\
\text { itp. } \\
\text { do tej grupy włą- } \\
\text { czono podatki od } \\
\text { produktów ener- } \\
\text { getycznych użyt- } \\
\text { kowanych w tran- } \\
\text { sporcie, takie jak: } \\
\text { benzyna, diesel. } \\
\text { do tej grupy należą } \\
\text { również podatki } \\
\text { od emisji dwutlen- } \\
\text { ku węgla. }\end{array}$ & $\begin{array}{l}\text { Podatki od środków } \\
\text { transportu: } \\
-\quad \text { podatki związane z } \\
\text { posiadaniem i użyt- } \\
\text { kowaniem pojaz- } \\
\text { dów motorowych. } \\
\text { - } \quad \text { również podatki } \\
\text { dotyczące innych } \\
\text { środków transpor- } \\
\text { tu, takich jak samo- } \\
\text { loty i statki. } \\
\text { - podatki towarzy- } \\
\text { szące usługom } \\
\text { transportowym (np. } \\
\text { chartery), o ile } \\
\text { spełniajá definicję } \\
\text { podatków i defini- } \\
\text { cje podatków śro- } \\
\text { dowiskowych. }\end{array}$ & $\begin{array}{l}\text { Podatki od zanieczysz- } \\
\text { czeń: } \\
\text { - } \quad \text { podatki związane } \\
\text { z pomierzonymi lub } \\
\text { przewidywanymi za- } \\
\text { nieczyszczeniami } \\
\text { wprowadzanymi do } \\
\text { powietrza i wody } \\
\text { (z wyłączeniem } \\
\mathrm{CO}_{2} \text { ). } \\
\text { również podatki do- } \\
\text { tyczacce gospodaro- } \\
\text { wania odpadami sta- } \\
\text { łymi i hałasu, o ile } \\
\text { spełniają definicję } \\
\text { podatków i definicję } \\
\text { podatków środowi- } \\
\text { skowych. }\end{array}$ & $\begin{array}{l}\text { Podatki od zasobów na- } \\
\text { turalnych: } \\
\text { - } \quad \text { podatki od eksploat- } \\
\text { owanych zasobów } \\
\text { naturalnych (np. po- } \\
\text { datek górniczy, po- } \\
\text { datki od poboru wo- } \\
\text { dy i użytkowania la- } \\
\text { sów, flory i fauny). } \\
\text { wyłączone są po- } \\
\text { datki od ropy naf- } \\
\text { towej i gazu ziem- } \\
\text { nego oraz podatki } \\
\text { związane z posiada- } \\
\text { niem ziemi. }\end{array}$ \\
\hline
\end{tabular}

Źródło: opracowanie własne na podstawie materiałów Eurostatu.

Nie jest oczywiste, z jakich powodów dokonano przesunięć i kilku wyłączeń w odniesieniu do znaczących pozycji podatków, takich jak: paliwa, zasoby paliw kopalnych, zasoby ziemi. Ponadto, z wyjątkiem bardzo szczególnych sytuacji, wyłącza się z rozważań podatek VAT. Dyskusja na temat tych rozwiązań znajduje się w dalszej części artykułu.

\section{Analiza metodyki Eurostatu}

Dokonana przez Eurostat definicja podatków środowiskowych w kilku punktach odbiega od rozwiązań stosowanych w wielu zestawieniach krajowych, a także w ,liberalnych” publikacjach OECD, gdzie podatki o podstawie środowiskowej (environmentally related taxes) to prawie wszystkie zobowiązania lub płatności, które powstają z tytułu bezpośredniego lub pośredniego związku ze środowiskiem przyrodniczym i jego zasobami ${ }^{3}$.

W metodyce Eurostatu autora tego artykułu interesuje wyłącznie negatywne oddziaływanie na środowisko, skutkujące: zubożeniem zasobów naturalnych, zanieczyszczaniem środowiska i innymi formami pogarszania jakości środowiska w skali lokalnej i globalnej. Podatkiem środowiskowym jest zobowiązanie lub płatność, które zostały zidentyfikowane w ramach metodyki ESA'95 jako podatek, którego pod-

3 Podejście OECD tłumaczy na przykład publikacja: [The Political Economy of Environmentally Related Taxes, 2006]. 
stawa jest jednostka fizyczna o bezpośrednim lub pośrednim i naukowo udowodnionym, negatywnym wpływie na środowisko.

Nie jest oczywiste, dlaczego dla celów statystycznych badaniem nie obejmuje się wpływów podatkowych, które powstają w wyniku pozytywnych działań na rzecz środowiska. Podatki związane z pozytywnym oddziaływaniem na środowisko warto ewidencjonować. $W$ krajach, które osiagnęły zadowalający poziom ochrony środowiska, ukształtował się z reguły silny sektor przemysłu ochrony środowiska, na przykład w Danii. Jego opodatkowanie, podobnie jak podatki ściagane $z$ tytułu rozwoju i korzystania z chronionych lub odtwarzanych walorów środowiska, mogłoby zostać zaliczone do podatków środowiskowych. Wówczas kategoria podatków środowiskowych nie wykazywałaby wyłącznie wpływów pieniężnych z tytułu zużywania zasobów i degradacji środowiska, ale również z tytułu zarządzania środowiskiem w aspekcie trwałego i zrównoważonego rozwoju - ochrona walorów środowiska połączona z: tworzeniem miejsc pracy, wzrostem gospodarczym i wzrostem poziomu życia.

Podążając dalej tym tropem, można zapytać, dlaczego rezygnuje się z ewidencjonowania subwencji na rzecz działań korzystnych dla środowiska, które są dla Skarbu Państwa „ujemnymi podatkami”. Wiele instytucji międzynarodowych, z OECD na czele, poświęca mnóstwo czasu i energii na programy zmierzające do identyfikowania błędnych, gdyż szkodliwych dla środowiska, subwencji (perversive incentives). Chodzi o subwencje, które wspomagając realizację pewnych celów społeczno-gospodarczych, prowadza jednocześnie do degradacji środowiska. Natomiast stosunkowo mało uwagi poświęca się subwencjom, które służą środowisku. Brak subwencji w projekcie podatkowym będzie wystarczająco uzasadniony, jeżeli zostaną one umieszczone i właściwie ujęte w innym segmencie badań Eurostatu nad wydatkami na ochronę środowiska.

Z koncepcji podatków od działalności szkodliwej dla środowiska wynika następująca kontrowersja dotycząca interpretacji danych statystycznych o wysokości kwot zebranych podatków. Zbierając dane podporządkowane przemyślanej metodyce, powinno uzyskiwać się jednorodną i łatwą do zinterpretowania informację. Jak odczytywać wzrost wpływów z podatków nałożonych na negatywne oddziaływania? Bardzo wątpliwie brzmi argument, że wzrost wpływów z takich podatków pokazuje wzrost troski o środowisko. Bliższa prawdy jest teza, że fiskalna rola tych podatków w praktyce przeważa nad ich funkcją bodźcowa. Wpływy podatkowe są zatem daniną za szkody wyrządzone środowisku, która nie pozostaje w żadnej proporcji do całkowitej wartości poniesionych strat. Uzyskane przychody moga, ale nie muszą, zostać przeznaczone na rekompensowanie szkód lub uniknięcie ich w przyszłości.

Tak więc, wzrost wpłaconych kwot nie musi wcale oznaczać, że presja na środowisko została lub zostanie w ogóle złagodzona, jak również nie ma pewności, że zgromadzone środki będą w ogóle zastosowane na rzecz poprawy jakości środowiska. W przypadku podatków od działalności szkodliwej, jedynym miernikiem, którego wzrost można odczytywać z uzasadnionym zadowoleniem jest większy udział podatków środowiskowych w całości wpływów podatkowych. Taka ewolucja byłaby zresztą pożądana i zgodna z bardzo ogólnymi wytycznymi ekologicznej reformy podatkowej.

Kolejnym krokiem w zastosowaniu przyjętej metodyki jest dokonanie podziału podatków środowiskowych na cztery grupy: podatki energetyczne (energy tax), podatki 
transportowe (transport tax), podatki od zasobów naturalnych (resources tax), podatki od zanieczyszczeń (pollution tax). To rozróżnienie jest tylko z pozoru oczywiste, a to z powodu szczególnego potraktowania podatków energetycznych, a także z racji licznych, proponowanych wyłączeń podatków, które można byłoby zaliczyć do jednej z pozostałych grup podatków środowiskowych.

W klasyfikacji Eurostatu bezdyskusyjny „priorytet” przyznano środowiskowym konsekwencjom, których źródło tkwi w użytkowaniu energii. Tym samym, na przykład środki mające zastosowanie opałowe i napędowe, o ile nałożone są na nie podatki, generują kwoty, które zaliczane są do podatków energetycznych. Zatem, paliwa wykorzystywane w transporcie, które w innych schemacie klasyfikacyjnym mogłyby zostać zaliczone do grupy podatków transportowych, są tutaj uznawane za podatki energetyczne. Co więcej, metodyka radzi zaliczyć podatki od emisji dwutlenku węgla do kategorii podatków od energii.

Z kolei, w kategorii podatków zasobowych podjęto dość arbitralną decyzję polegającą na wykluczeniu z rozważań podatków od wydobycia ropy naftowej i gazu ziemnego. Podstawą tej decyzji jest obserwacja, w jak dużym stopniu wpływ na wysokość podatku ma w wielu krajach interwencyjna polityka państwa posiadającego takie zasoby. Uznano, że podatek może odgrywać rolę swoistej renty, wynikającej z rzadkości zasobu lub warunków jego pozyskiwania. Włączenie podatków od ropy naftowej i gazu ziemnego, zdaniem pomysłodawców, zdecydowanie zaburzyłoby porównywalność, w wymiarze międzynarodowym, danych statystycznych w kategorii podatków energetycznych.

Podobne kontrowersje towarzyszą wyeliminowaniu z zestawienia podatków związanych z ziemią. Uznano, że dane z różnych krajów będą za bardzo niejednorodne, ponieważ pomieszane zostana podatki od posiadania ziemi z podatkami biorącymi za podstawę opodatkowania powierzchnię, a nawet rodzaj lub jakość gleby będącej w rolniczym, ewentualnie hodowlanym, użytkowaniu.

Watpliwości może również budzić usunięcie z kategorii podatków środowiskowych grupy opłat środowiskowych, interpretowanych jako zapłata za świadczenie. W tym zakresie metodyka odchodzi od, najczęściej dotychczas stosowanych, rozwiązań, gdyż interpretuje świadczenie w sposób stosunkowo dowolny. Wiadomo, że nie zawsze daje się jasno i bez zastrzeżeń zastosować regułę, że uiszczenie podatku nie uprawnia do żadnego świadczenia, które miałoby być gwarantowane w formie usługi, a ponadto nie jest proporcjonalne do zakresu świadczonej usługi. Sa takie kraje, należy do nich także Polska, gdzie opłaty za gospodarcze użytkowanie środowiska tworzą rozbudowany system, generuja znaczne dochody dla Skarbu Państwa, a jednocześnie sa publicznie uzasadniane jako pieniężne zadośćuczynienie za udostępnienie środowiska, co w pewnych sytuacjach przypomina formę publicznej usługi.

Na przykładach warto zauważyć, jakie są konsekwencje przyjętej metodyki. Bardzo popularny w Polsce instrument ekonomiczny, jakim jest opłata za wprowadzenie do środowiska zanieczyszczeń do powietrza, raczej spełnia pierwszy warunek - nie ma świadczenia usługi, a więc jest podatkiem od zanieczyszczeń w rozumieniu przyjętej metodyki. Na tej samej zasadzie opłata za pobór wody, która również spełnia pierwszy warunek, może zostać potraktowana jako podatek od zasobów naturalnych. Jednakże opłata za umieszczenie odpadów na wysypisku jest w tej nomenklaturze opła- 
ta środowiskowa, a nie podatkiem, ponieważ w rozumieniu metodyki Eurostatu jest to proporcjonalnie naliczona zapłata za usługę udostępnienia dostarczycielowi odpadów specjalnie przygotowanego składowiska.

Zgodnie z metodyką Eurostatu, należności, które nie znajdą się w grupie podatków środowiskowych, mają być identyfikowane i liczone jako „inne opłaty związane ze środowiskiem" (other environmentally relevant payments). Z racji wyrażonych powyżej wattpliwości, trzeba stwierdzić, że to dobrze, iż nie zrezygnowano z ich ewidencjonowania i umieszczenia w końcowym, sprawozdawczym formularzu. Natomiast brakuje klarownych wskazówek, w jakim celu takie dane mają być osobno gromadzone. Czy chodzi o to, że kryterium kwalifikujące, co jest, a co nie jest, usługa postrzega się jako niedoskonałe? Czy też pomysłodawcy liczą się w przyszłości z uwzględnieniem tych wpływów finansowych w nowej, poszerzonej formule podatków środowiskowych?

W metodyce Eurostatu pozostawiono na uboczu kwestię, dokąd sa kierowane pozyskane środki. Zwykle uważa się, że podatki wędrują do Skarbu Państwa lub jego funduszy celowych, natomiast opłaty mogą być gromadzone i wykorzystane w inny sposób. To rozumowanie nie znajduje istotnego zastosowania w opracowaniach Eurostatu. Tak więc i w tym miejscu zaznacza się myślenie, które nie bierze pod uwagę specyfiki krajów członkowskich. Tymczasem wśród nowych członków Unii Europejskiej jest kilka krajów, które w okresie transformacji postawiło na fundusze ochrony środowiska i ich wiodąca rolę w polityce poprawy stanu środowiska. Natomiast fundusze celowe są z reguły podporządkowane Skarbowi Państwa, ale zachowują mniej lub bardziej rozbudowaną niezależność.

Polska posługuje się rozbudowanym systemem podatków, opłat i kar związanych z gospodarczym korzystaniem ze środowiska, które trafiają do funduszy ochrony środowiska i gospodarki wodnej ${ }^{4}$. Zgodnie z obowiązującym prawem, transferowane tam środki pieniężne nie znajdują się w gestii Ministra Finansów. Nota bene, jest to przedmiotem przetargów i wielu kontrowersji między Ministerstwem Finansów a Ministerstwem Środowiska. Z perspektywy Polski istotne wydaje się przedstawienie w sprawozdaniu, że ogólna kwota podatków związanych ze szkodliwym oddziaływaniem na środowisko $w$ przeważającej części jest $z$ góry przeznaczona na finansowanie poprawy stanu środowiska. Takie ,szufladkowanie” (earmarking) nie cieszy się uznaniem ekonomistów, domagających się wysokiej efektowności wydatków publicznych, ale ma swoje oczywiste uzasadnienie w okresie transformacji, kiedy na pierwszy plan wysuwa się skuteczne i stosunkowo szybkie osiagnięcie zadowalającej jakości środowiska.

Trudności metodyczne wynikają również z faktu, że nie zawsze jest możliwe jednoznaczne i pewne przypisanie istniejących podatków do wyróżnionych w projekcie grup rodzajowych, takich jak: energia, transport, zanieczyszczenia, zasoby naturalne. Stąd na przykład, wśród ewidencjonowanych w Polsce podatków akcyzowych, znajduje się duża część podatków od: surowców, pólproduktów, produktów, które moga, lecz nie musza, zostać wykorzystane jako paliwo.

4 Autor wypowiadał się na temat polskich opłat i podatków w swoich licznych publikacjach, na przykład: [Economic instruments..., 1998, s. 30-67; Śleszyński, 2000; Śleszyński, 2004]. Najnowsza publikacją wyczerpująco opisującą krajowy system opłat i podatków środowiskowych, jest książka Małeckiego [Małecki, 2012]. 
Wymagania klasyfikacyjne mówią jasno, że podatki związane z wykorzystaniem energii lub nośników energii do celów napędowych lub opałowych mają być zaliczane zawsze do grupy podatków energetycznych, a nie podatków od zasobów naturalnych. Zatem, to wymaganie stawia przed decydentem problem: jak postąić w sytuacji, gdy przedmiot opodatkowania może być zarówno produktem energetycznym, jak i surowcem do dalszego przetwarzania, niezwiązanym z generowaniem energii?

W sytuacji, gdy wyliczona w krajowej klasyfikacji kategoria podatku budziła takie wątpliwości, zazwyczaj stosowano zasadę „większościową. Polegała ona tym, że podatek zaliczano do danej grupy, jeżeli przeważająca część podatku, w ujęciu wartościowym, pochodziła z przedmiotów opodatkowania służących celom energetycznym. Ten rodzaj kwalifikacji podatków nie jest precyzyjny i może prowadzić do przeszacowania, a więc wymaga w przyszłości dokładniejszych badań statystycznych i być może dezagregacji pewnych kategorii podatków.

Co więcej, opisane powyżej, „,większościowe” kwalifikowanie do danej grupy, nawet po poprawkach opartych na badaniach empirycznych, dotyczące wykorzystania poszczególnych surowców lub półproduktów, nie uniknie błędu wynikającego z praktyki życia codziennego. Kwalifikacja przedmiotów opodatkowania, według ich głównego sposobu wykorzystania, nie może bowiem brać pod uwagę „energetycznej szarej strefy”, w której występuje, mniej lub bardziej niezgodne z prawem, wykorzystanie do celów energetycznych: surowców, półproduktów, zużytych produktów lub odpadów, które nie były przeznaczone do spalania.

Kolejnym problemem do rozwiazania jest konfrontacja obserwowanego funkcjonowania podatków z intencjami podatkobiorcy. Ustalając podatki, państwo kieruje się stosunkowo czytelnymi przesłankami. Mogą one mieć prostą motywacje fiskalna - ściagnięcie z gospodarki i obywateli odpowiednich kwot do Skarbu Państwa. Jednak często motywacje są bardziej złożone, ponieważ łączą się jednocześnie z realizacją kilku celów. Mogą to być cele związane ze stwarzaniem lepszych warunków rozwojowych określonym gałęziom gospodarki lub branżom. Moga to być również motywacje z dziedziny polityki społecznej - łagodzenie ciężaru podatkowego dla wybranych grup społecznych. Moga to być wreszcie motywacje, które daja się przypisać, szeroko rozumianej, polityce ochrony środowiska.

W sytuacji wyraźnego lub podejrzewanego konfliktu intencji ustalonych podatków z ich faktycznym funkcjonowaniem, najlepsze wydaje się podejście „realistyczne”, a więc takie, które bierze pod uwagę występowanie lub niewystępowanie skutków dla środowiska istniejącego opodatkowania. Natomiast w sytuacji, gdy intencje ustawodawcy nie były raczej środowiskowej natury, ale można było spodziewać się zmiany zachowań podmiotów gospodarczych lub konsumentów, polegającej na zmniejszeniu zużycia zasobów naturalnych albo złagodzeniu presji wywieranej na środowisko, kwalifikowano dane podatki do grupy obejmującej podatki od zasobów bądź do grupy podatków od zanieczyszczeń. 


\section{Tworzenie listy krajowych podatków środowiskowych}

Należy wyraźnie podkreślić, że identyfikacja wszystkich krajowych podatków, które wiaża się z działalnością szkodliwą dla środowiska i mogą zostać uznane za podatki środowiskowe, zgodnie z przyjętą metodyką Eurostatu, ma w naszym kraju charakter pionierski. Stąd wiele trudności i wątpliwości próbowano rozstrzygać w ramach zespołu badawczego Grupy Zadaniowej do spraw Rachunków Środowiskowych oraz w kontaktach ze specjalistami z różnych dziedzin.

Kategorie, znanych obecnie, krajowych podatków nie są wewnętrznie jednorodne, jeżeli chodzi o oddziaływanie na środowisko. Nikt do tej pory nie dopominał się o zwrócenie uwagi na cechę podatku dotyczącą wpływu na środowisko i szkodliwości przedmiotu opodatkowania. W szczególności, konstruując większość podatków, nie badano nawet, czy i w jakim stopniu moga mieć związek ze środowiskiem. Poniżej przedstawiono tylko wybrane problemy decyzyjne i sposoby rozstrzygania najważniejszych kontrowersji łączących się z wyróżnieniem podatków środowiskowych i przyporządkowaniem ich do jednej z czterech grup.

\section{Podatki od energii}

Postanowiono, że analizowane podatki akcyzowe, dotyczące nośników energii, sa podatkami środowiskowymi o podstawie energetycznej. O zakwalifikowaniu do grupy podatków od energii przesądzało wyraźne określenie tych podatków w samym tytule, jako podatków nałożonych na przedmioty opodatkowania służące do celów opałowych lub napędowych. Do podatków środowiskowych od energii zaliczono również: opłaty zastępcze za niewywiązanie się z narzuconych limitów zastosowania energii odnawialnej i opłaty paliwowe.

Dużo watpliwości budziły podatki związane $\mathrm{z}$ wydobywaniem różnych kopalin. W trakcie kwalifikowania tych podatków pojawiły się obiekcje wynikające z niejednorodności przedmiotu opodatkowania umieszczonego w danej kategorii podatku. $\mathrm{Na}$ przykład kilka $z$ wymienionych kategorii zawierało w sobie przedmioty opodatkowania o charakterze energetycznym oraz zasobowo-surowcowym. Trzeba było arbitralnie przesądzić, czy mogą zostać zaliczone do podatków od energii.

Kolejnym problemem były cła. $Z$ natury rzeczy, cło przywozowe dotyczy: surowców, materiałów, produktów wwożonych do kraju, a więc w przypadku zubożenia lub pogorszenia stanu zasobów naturalnych istotny wpływ na środowisko zaistniał już wcześniej i na dodatek poza krajem. Zasadnicze zastrzeżenie łączyło się z decyzją, czy w rachunku podatków środowiskowych danego kraju należy ujmować negatywny wpływ na środowisko poza granicami tego kraju. Zrezygnowano $z$ takiego rozumowania, ponieważ metodyka nie zawierała takiej wskazówki. Przyjmując powyższe założenia, postanowiono nie uwzględniać w zestawieniu podatków środowiskowych innych kategorii, niż cła związane z importem nośników energii i sprowadzaniem do kraju środków transportu. Te wymieniono na drugim miejscu, oczywiście tylko w kategorii podatków od transportu. 
W krajowym systemie opłat za gospodarcze korzystanie ze środowiska istotna pozycję zajmuja opłaty za wprowadzanie zanieczyszczeń do powietrza. Wśród nich znajdują się opłaty za emisje dwutlenku węgla, które zgodnie z metodyka, należy włączyć do grupy podatków od energii. Stawki opłat sa znane, a także można stosunkowo dokładnie szacować krajowe emisje $\mathrm{CO}_{2}$. Jednak na tym etapie podjęto decyzję o niewydzielaniu tych opłat. Narodowy Fundusz Ochrony Środowiska i Gospodarki Wodnej nie dysponuje odpowiednimi danymi o wpływach z tytułu opłat za emisje $\mathrm{CO}_{2}$. Wydzielenie opłat za $\mathrm{CO}_{2}$ będzie wymagało zwrócenia się do samorządów, gdyż opłaty za powietrze sa pobierane na różnych poziomach administracji państwowej. Takie zadanie badawcze zostanie postawione i rozwiązane w przyszłości.

\section{Podatki od transportu}

Do grupy podatków środowiskowych od środków transportu zaliczono: akcyzę na samochody osobowe, cło na importowane pojazdy, statki powietrzne, jednostki pływające oraz współdziałające urządzenia transportowe, jak również opłaty rejestracyjne i ewidencyjne pojazdów, podatek od środków transportowych. Z pewnym wahaniem włączono do tych podatków opłatę za brak sieci zbierania pojazdów. Natomiast zrezygnowano z uwzględniania podatków i opłat lokalnych o małym znaczeniu, na przykład opłat za „Dokonanie wpisu statku rybackiego do rejestru statków rybackich”. Uwzględniono w tej grupie podatków cła związane z importem środków transportu.

\section{Podatki od zanieczyszczeń}

Kluczową decyzją było przesądzenie, że występujące w krajowej polityce ochrony środowiska, bardzo liczne i silnie zróżnicowane, opłaty za gospodarcze korzystanie ze środowiska zostaną zaliczone do podatków środowiskowych. Prawie wszystkie, zgodnie ze swoją rolą i przeznaczeniem, zostały zaliczone do grupy podatków od zanieczyszczeń (wprowadzanie zanieczyszczeń do powietrza, zanieczyszczanie wód), a tylko nieliczne uznano za podatki od zasobów naturalnych (pobór wody, usuwanie drzew i krzewów).

Do grupy podatków środowiskowych od zanieczyszczeń należą opłaty za korzystanie ze środowiska, które w polskim systemie finansowania ochrony środowiska trafiają do funduszy celowych ochrony środowiska i gospodarki wodnej. Najważniejsze z nich to: „Opłaty za wprowadzenie substancji ze ściekami do wód lub do ziemi”, „Opłata za wprowadzanie do wód lub do ziemi wód chłodniczych”, „Opłaty za powierzchnie zanieczyszczone o trwałej nawierzchni, z których są wprowadzane do wód lub do ziemi wody opadowe lub roztopowe, ujęte w otwarte lub zamknięte systemy kanalizacyjne, z wyjątkiem kanalizacji ogólnospławnej”, „Opłaty za gazy lub pyły wprowadzane do powietrza”, „Opłaty za gazy wprowadzane do powietrza powstające przy przeładunku benzyn silnikowych”, „Opłaty za gazy lub pyły wprowadzane do powietrza z kotłów o nominalnej mocy cieplnej do $5 \mathrm{MW}$ opalanych: węglem kamiennym, koksem, drewnem, olejem lub paliwem gazowym, dla których nie jest wymagane 
pozwolenie na wprowadzanie gazów lub pyłów do powietrza albo pozwolenie zintegrowane”, „Opłaty za gazy lub pyły wprowadzane do powietrza z procesów spalania paliw w silnikach spalinowych”, „Opłaty za gazy lub pyły wprowadzane do powietrza z chowu lub hodowli drobiu".

Do podatków środowiskowych od zanieczyszczeń zaliczono wszystkie opłaty produktowe i produktowo-depozytowe. Dodatkowy komentarz musi dotyczyć opłat depozytowych, które są zwracane w przypadku dostarczenia zużytego produktu na odpowiednie miejsce. W rachunku wpływów z tych podatków będzie konieczne określenie efektu „netto” - różnicy między kwotami wpłacanymi i zwracanymi.

Do podatków środowiskowych od zanieczyszczeń włącza się opłatę za emisję gazów zubażających warstwę ozonową, a także wszystkie opłaty podwyższone i dodatkowe związane $z$ emisjami i zanieczyszczeniami. O ile te pierwsze nie sa kłopotliwe, to rachunek opłat podwyższonych i dodatkowych będzie wymagał czasu i znacznego zaangażowania instytucji biorących udział w wymierzaniu i ściaganiu tych opłat. $\mathrm{Z}$ tego powodu te opłaty nie zostały jeszcze włączone do drugiego etapu projektu.

Istotna wątpliwość łączy się z faktem, że podatki, które wskazują na zapłatę z tytułu użytkowania zasobów nieodnawialnych i zasobów przyrodniczych, są wyjątkowo niejednorodne i w oczywisty sposób zawierają również półprodukty i wyroby gotowe. Mogą mieć one szkodliwy wpływ na środowisko, ale zidentyfikowanie go i potwierdzenie jest zbyt skomplikowane, żeby kontynuować ten sposób interpretacji. Dlatego nie włączono do podatków od zanieczyszczeń podatków, których przedmiot opodatkowania nie miał bezpośredniego, negatywnego wpływu na środowisko.

Z racji przyjętej metodyki „Opłaty za umieszczenie odpadów na składowisku” zostały zaliczone do opłat środowiskowych, a nie do grupy podatków od zanieczyszczeń. W tym przypadku rozstrzygające było stwierdzenie, że za zapłatę jest gwarantowana określona usługa dostarczana użytkownikowi składowiska i że kwota do zapłaty została określona proporcjonalnie do wielkości i rodzaju przyjętych odpadów.

\section{Podatki od zasobów naturalnych}

Wyodrębniono również podatki środowiskowe od zasobów naturalnych. W szczególności są to: „Opłaty za pobór wody podziemnej i wody powierzchniowej śródladowej” i „Opłaty za usuwanie drzew i krzewów”. W tej grupie istotna decyzja polegała na stwierdzeniu, że polską opłatę za pobór wody należy traktować jako podatek od użytkowanego zasobu naturalnego, a nie opłatę środowiskowa za uzyskaną usługę. Jeżeli chodzi o gospodarkę wodna, nie jest to oczywiste stwierdzenie,, ale pozostaje w zgodzie ze środowiskową strategia oszczędnego użytkowania zasobów wodnych (zwłaszcza wody najwyższej jakości) i to nawet jeżeli zasoby wodne mają cechę odnawialności.

Niektóre kategorie podatków zawierały zarówno surowce do dalszego chemicznego przetworzenia, jak i minerały i związki chemiczne czerpane bezpośrednio ze środowiska. W takiej sytuacji trzeba było przesądzić, czy dana kategoria zostanie zaliczona do podatków związanych z uszczupleniem zasobów, czy do podatków od 
zanieczyszczeń. Stwierdzono, że w rozważanych przypadkach wchodzi w rachubę zanieczyszczenie środowiska, lecz ostatecznie te podatki zostały pominięte na liście podatków środowiskowych. Zadecydowała wskazówka, że metodyka nie zajmuje się łańcuchem oddziaływań potencjalnie szkodliwych dla środowiska, które mogą towarzyszyć: wydobyciu, transportowi lub przetwarzaniu surowców i półproduktów. Wpływ na środowisko zostanie odzwierciedlony o tyle, o ile pobierany jest podatek od konkretnych zanieczyszczeń.

\section{Inne opłaty i podatki związane ze środowiskiem}

Rozpatrując budżety lokalne, stwierdzono, że niektóre ściągane opłaty skarbowe moga spełniać wymogi stawiane podatkom środowiskowym, ponieważ są to jednorazowe opłaty niepowiazzane proporcjonalnie $z$ negatywnym wpływem prowadzonej działalności na środowisko. Dzięki wniesieniu opłaty, podmiot gospodarczy zyskuje prawo do określonego użytkowania środowiska lub do prowadzenia działalności wpływającej negatywnie na jakość środowiska.

Wśród opłat skarbowych za dokonanie czynności urzędowych wyodrębniono te, których konsekwencja jest wprowadzanie zanieczyszczeń do środowiska: „Przyjęcie wymaganego przepisami o ochronie środowiska zgłoszenia instalacji, z której emisja nie wymaga pozwolenia, mogącej negatywnie oddziaływać na środowisko”, „Decyzja zatwierdzająca program gospodarowania odpadami niebezpiecznymi”, „Decyzja o środowiskowych uwarunkowaniach zgody na realizację przedsięwzięcia”, „Decyzja zatwierdzająca instrukcję eksploatacji składowiska”. Ostatecznie postanowiono nie włączać ich do grupy podatków od zanieczyszczeń z dwóch powodów. Po pierwsze, wynikiem wydania pozwolenia jest emisja zanieczyszczenia, za które i tak pobiera się opłatę. Po drugie, kwoty opłat za dokonanie czynności urzędowych są stosunkowo małe.

Podobnie, jak z opłatami za dokonanie czynności urzędowych, postapiono z opłatami skarbowymi dotyczącymi wydania zezwoleń na prowadzenie działalności potencjalnie szkodliwej dla środowiska. Wśród nich były, takie jak: „Licencja połowowa”, „Sportowe zezwolenie połowowe”, „Pozwolenie albo zezwolenie na: połowy organizmów morskich w celach naukowo-badawczych albo szkoleniowych”, „Pozwolenie wodnoprawne”, „Pozwolenie wydawane na podstawie przepisów o zapobieganiu zanieczyszczaniu morza przez statki”, „Zezwolenie na dopuszczenie środka ochrony roślin do obrotu i stosowania, wydawane na podstawie przepisów o ochronie roślin”, „Pozwolenie na wprowadzanie substancji i energii do środowiska, wydawane na podstawie przepisów o ochronie środowiska i przepisów o odpadach”, „Zezwolenie na wykonywanie działalności w zakresie odbierania odpadów komunalnych od właścicieli nieruchomości”, „Zezwolenie na wykonywanie działalności w zakresie opróżniania zbiorników bezodpływowych i transportu nieczystości ciekłych". Szkodliwość dla środowiska pojawia się dopiero $\mathrm{w}$ momencie wykorzystania pozwolenia, a kwoty ściąganych opłat są niewielkie w porównaniu z innymi wpływami podatkowymi. 
Zrezygnowano również z zaliczenia do podatków środowiskowych następujących podatków i opłat lokalnych: „Opłaty uzdrowiskowej” i „Opłaty miejscowej”. Z jednej strony, są one wprost związane z użytkowaniem środowiska, ale szkodliwy wpływ na środowisko nie jest oczywisty. $Z$ drugiej strony, zaliczenie tych opłat do grupy podatków od zasobów naturalnych również nie wchodziło w rachubę z powodu, zawartej w metodyce, ściśle gospodarczej koncepcji zasobów naturalnych.

W tabeli 3. przedstawiono roboczą wersję listy podatków, uwzględniającą $22 \mathrm{ka-}$ tegorie podatków (w układzie U22). Sformułowanie listy umożliwiło przejście do etapu drugiego i podjęcie próby określenia kwot krajowych podatków środowiskowych w podziale na płatników, według rodzaju działalności.

Wcześniej rozważano listę, na którą składało się 19 pozycji (U19), lecz dokonano uzasadnionych modyfikacji. Kategorię „Akcyza na paliwa przeznaczone do celów opałowych do lub napędowych, z wyjątkiem gazu LPG” postanowiono przedstawić w postaci dwóch kategorii: osobno dla paliw opałowych oraz osobno dla paliw napędowych. Wprowadzono do zestawienia akcyzę na oleje smarowe. Kategoria „Opłaty za pobór wody podziemnej i wody powierzchniowej śródlądowej” będzie, jak zostało to wcześniej wyjaśnione, zaliczona do podatków zasobowych, jednak nie występuje $\mathrm{w}$ aktualnym zestawieniu z powodu problemów ze zdobyciem kompletnych danych. Planowane jest pozyskanie tych danych z Urzędów Marszałkowskich. Kategorię opłat produktowych za: opakowania, baterie i akumulatory, oleje smarowe i opony postanowiono, z powodów praktycznych, rozdzielić na cztery kategorie podatków. Tymczasowo zawieszono zajęcie się opłatami podwyższonymi i dodatkowymi, ze względu na ograniczoną dostępność danych, lecz nie ma powodu, żeby w przyszłości wyłączać je z grupy podatków od zanieczyszczeń.

W rezultacie, w układzie U22, przyjętym jako punkt wyjścia do drugiego etapu projektu, zidentyfikowano 22 podatki środowiskowe (są to podatki kolejno ponumerowane w tabeli 3.): 7 podatków od energii, 5 podatków od transportu, 9 podatków od zanieczyszczeń oraz 1 podatek od zasobów naturalnych.

Należy mieć na względzie opłaty, które zgodnie z metodyką, nie moga zostać uznane za podatki środowiskowe, ale dotyczą aktywnej polityki państwa i skupiają się na nałożeniu opłat na te rodzaje aktywności, które mają negatywny wpływ na środowisko. Na etapie drugim zostana zidentyfikowane i wykazane opłaty środowiskowe, które materiały szkoleniowe określaja jako opłaty związane ze środowiskiem (environmentaly related payments).

Godne uwagi są również opłaty, których nie ma na liście, a mogą być brane pod uwagę w przyszłości. Na ich temat nie wypowiada się metodyka, lecz niewykluczone, że po konsultacji z Eurostatem znajdą się w kregu zainteresowania podatków środowiskowych. Pierwsza opłata obejmuje: „Zgody i zezwolenia wydawane na podstawie przepisów o organizmach genetycznie zmodyfikowanych: 1) zgoda na uwolnienie GMO do środowiska albo na zamknięte użycie GMO, 2) zezwolenie na wprowadzenie do obrotu produktów GMO oraz na wywóz lub tranzyt produktów". Zawirowania prawne i naukowe oraz społeczne debaty zwiazzane z GMO skłaniają do odłożenia na później kwestii klasyfikacyjnych. Jednak można zasugerować, że jedną z możliwych interpretacji mogłoby być uznanie wymienionej opłaty za podatek od „biologicznego zanieczyszczenia” środowiska. 
TABELA 3.

Krajowe podatki środowiskowe w układzie U22

\begin{tabular}{|c|c|c|}
\hline Lp. & Podatki & Przedmiot opodatkowania \\
\hline 1. & Akcyza na paliwa przeznaczone do celów opałowych & Energia \\
\hline 2. & Akcyza na paliwa przeznaczone do celów napędowych & Energia \\
\hline 3. & Akcyza na gaz LPG & Energia \\
\hline 4. & Akcyza na energię elektryczną & Energia \\
\hline 5. & Akcyza na samochody osobowe & Transport \\
\hline 6. & Akcyza na oleje smarowe & Zanieczyszczenia \\
\hline 7. & $\begin{array}{l}\text { Cło na importowane paliwa mineralne, oleje mineralne i pro- } \\
\text { dukty ich destylacji, substancje bitumiczne, woski mineralne }\end{array}$ & Energia \\
\hline 8. & $\begin{array}{l}\text { Cło na importowane pojazdy, statki powietrzne, jednostki } \\
\text { pływające oraz współdziałające urządzenia transportowe }\end{array}$ & Transport \\
\hline 9. & Opłaty rejestracyjne i ewidencyjne pojazdów & Transport \\
\hline 10. & Podatek od środków transportowych & Transport \\
\hline 11. & $\begin{array}{l}\text { Opłaty za substancje wprowadzane ze ściekami do wód lub } \\
\text { do ziemi }\end{array}$ & Zanieczyszczenia \\
\hline $\mathrm{X}$ & $\begin{array}{l}\text { Opłaty za pobór wody podziemnej i wody powierzchniowej } \\
\text { śródlądowej }\end{array}$ & Zasoby naturalne \\
\hline 12. & Opłaty za gazy lub pyły wprowadzane do powietrza & $\begin{array}{c}\text { Zanieczyszczenia } \\
\text { (opłata za emisję } \mathrm{CO}_{2} \text { to podatek od } \\
\text { energii, ale zostanie ona wyodrębniona } \\
\text { z tej kategorii w przyszłości) }\end{array}$ \\
\hline 13. & Opłaty produktowe za baterie i akumulatory & Zanieczyszczenia \\
\hline 14. & Opłaty produktowe za opony & Zanieczyszczenia \\
\hline 15. & Opłaty produktowe za opakowania & Zanieczyszczenia \\
\hline 16. & Opłaty produktowe za oleje smarowe & Zanieczyszczenia \\
\hline 17. & $\begin{array}{l}\text { Opłaty produktowe za zużyty sprzęt elektryczny i elektro- } \\
\text { niczny }\end{array}$ & Zanieczyszczenia \\
\hline 18. & Opłaty za usuwanie drzew i krzewów & Zasoby naturalne \\
\hline 19. & Opłata za brak sieci zbierania pojazdów & Transport \\
\hline 20. & Opłaty za substancje zubożające warstwę ozonową & Zanieczyszczenia \\
\hline 21. & $\begin{array}{l}\text { Opłaty zastępcze za niewykupienie wymaganej ilości energii } \\
\text { odnawialnej }\end{array}$ & Energia \\
\hline $\mathrm{X}$ & Opłaty podwyższone i dodatkowe & Zanieczyszczenia \\
\hline 22. & Opłata paliwowa & Energia \\
\hline
\end{tabular}

$\mathrm{X}$ - tak oznaczono w aktualnym zestawieniu podatki, których wysokość zostanie ustalona w przyszłości, po uzyskaniu dostępu do właściwych źródeł danych.

Źródło: opracowanie własne na podstawie materiałów Grupy Zadaniowej do spraw Rachunków Środowiskowych GUS oraz Departamentu Badań Regionalnych i Środowiska GUS. 
Drugi rodzaj opłat ściśle łączy się z europejskim systemem handlu pozwoleniami na emisje gazów szklarniowych (ETS): „Opłaty z tytułu handlu uprawnieniami do emisji gazów cieplarnianych”. Wydaje się, że z chwila powszechnego wprowadzenia nabywania pozwoleń na aukcji i egzekwowania opłat za emisje bez pozwoleń, oba tytuły do zapłaty będa miały charakter podatku od zanieczyszczeń. Tymczasem pozwolenia sa w większości rozdawane, a ich nabywanie na rynku pozwoleń jest uzależnione od zmiennych cen rynkowych pozwoleń, co czyni tę sytuację podobną do, wrażliwych na koniunkturę, cen ropy naftowej i gazu ziemnego. Stąd i te instrumenty również nie będa uwzględniane w prowadzonych obecnie pracach nad podatkami środowiskowymi.

\section{Podsumowanie}

$\mathrm{Na}$ podstawie przedstawionych zasad metodyki Eurostatu i krytycznej analizy tego podejścia można sformułować kilka retorycznych pytań, które warto adresować do autorów metodyki, niezależnie od zobowiązań Głównego Urzędu Statystycznego oraz realizowanego projektu badawczego. Są nimi:

- dlaczego w badaniu uwzględnia się tylko podatki związane z negatywnym wpływem na środowisko?

- $\quad$ czym jest uzasadnione wyjątkowe i preferencyjne traktowanie podatków energetycznych w porównaniu z pozostałymi grupami podatków?

- jaka jest oczekiwana interpretacja (pozytywna albo negatywna) danych o wielkości i trendach podatków środowiskowych?

Osobna grupę tworza problemy, które mają miejsce w trakcie tworzenia krajowej tablicy podatków środowiskowych. Napotkano dwie podstawowe trudności, które wymagaja głębszej analizy, bez względu na to, w jaki sposób udało się je pokonać w ramach projektu, a więc w początkowej fazie tworzenia krajowej sprawozdawczości podatków środowiskowych. Należą do nich:

- identyfikacja wszystkich podatków środowiskowych byłaby zbyt drobiazgowa, kosztowna i mało przydatna w praktyce, dlatego też należy skupić się tylko na kategoriach podatków o znaczącym wymiarze kwotowym, który powinien zostać dokładnie określony;

- ten sam przedmiot opodatkowania może być zarówno surowcem, jak i źródłem energii, a także źródłem zanieczyszczeń - w tych przypadkach jest potrzebna konsultacja z ekspertami z takich dziedzin, jak: geologia, energetyka, ochrona środowiska.

W przypadku niejednorodnej kategorii podatku trzeba dokonywać wyboru. Nie ma jednoznacznej wskazówki, która metoda byłaby preferowana. Reguła „większościowa" zaliczania do jednej z czterech grup podatków nie jest precyzyjna i wymaga weryfikacji. Na przyszłość jest potrzebne wypracowanie lepszej reguły klasyfikującej dla niejednorodnych kategorii podatków. Jednym z rozwiązań byłaby dezagregacja podatku na podkategorie o jasno określonej przynależności. Drugim rozwiązaniem byłoby szacowanie udziału we wpływach z tytułu danego podatku części dających się przypisać konkretnym grupom podatków. 
W artykule przedstawiono metodykę Eurostatu i zarysowano krajowe podejście do tego tematu, które zastosowano w ramach projektu. W pierwszym kwartale 2014 roku Eurostat dokona oceny materiałów Głównego Urzędu Statystycznego, obejmujących oba etapy projektu: identyfikację krajowych podatków w podziale na grupy podatków środowiskowych, a następnie określenie kwot krajowych podatków w podziale na płatników według rodzajów ich działalności. Po tej weryfikacji i uzyskaniu akceptacji Eurostatu będzie możliwe podanie do publicznej wiadomości ostatecznej listy krajowych podatków środowiskowych oraz danych liczbowych, które informują o wysokości wpływów z tych podatków z uwzględnieniem rodzaju działalności podatników.

\section{Literatura}

Baud S., Milota E. 2012 ESTP course on environmental taxes. Overview, powielony materiał informacyjny, Vienna, 23-25 May.

Economic instruments in Polish environmental policy 1998, [in:] Environmental Protection in Transition. Economic, (eds.) J. Clark, D.H. Cole, Legal and Socio-Political Perspectives on Poland, Ashgate, Aldershot.

Ekologiczna reforma podatkowa. Wyzwanie dla polskiej polityki ochrony środowiska 2004, J. Śleszyński (red.), Wydawnictwo Ekonomia i Środowisko, Białystok.

Environmental taxes - A statistical guide 2001, European Commission, EUROSTAT, Theme 2 Economy and finance, Methods and Nomenclatures, Luxembourg.

Ekologiczna reforma podatkowa. Wyzwanie dla polskiej polityki ochrony środowiska 2004, J. Śleszyński (red.), Wydawnictwo Ekonomia i Środowisko, Białystok.

Małecki P.P. 2012 System opłat $i$ podatków ekologicznych w Polsce na tle rozwiazan w krajach OECD, Wydawnictwo Uniwersytetu Ekonomicznego w Krakowie, Kraków.

Śleszyński J. 2000 Ekonomiczne problemy ocbrony środowiska, Agencja Wydawnicza Aries, Warszawa.

Śleszyński J. 2013 Opracowanie na temat rachunku podatków zwiazanych ze środowiskiem w zakeresie alokacii wielkości zagregowanych na grupy podatków, Uniwersytet Warszawski, Wydział Nauk Ekonomicznych, Warszawa, niepublikowane opracowanie: The Political Economy of Environmentally Related Taxes 2006, OECD, Paris.

Zmiany systemu oplat produktonych i oplat deposytonych w Polsce 2006, B. Fiedor, A. Graczyk (red.), Wydawnictwo Ekonomia i Środowisko, Białystok. 